\title{
Coal-Bed Methane: Potential and Concerns
}

\section{Introduction}

Methane (natural gas), while perhaps most closely related in our minds with petroleum, also occurs in association with coal, the Nation's most abundant fossil fuel resource. Conservative estimates (Rice, 1997) suggest that in the conterminous United States more than 700 trillion cubic feet (TCF) of coal-bed methane exists in place, with perhaps $100 \mathrm{TCF}$ economically recoverable with existing technology - the equivalent of about a 5year supply at present rates of use. Coalbed methane now accounts for about 7.5 percent of total natural gas production in the United States.

Scientific understanding of, and production experience with, coal-bed methane are both in the early learning stages. Much is yet to be learned (1) about the controls on the occurrence and recoverability of coal-bed methane-the geologic, geochemical, engineering, technological, and economic factors, for example-and (2) about the environmental implications of developing the resource. The coal-bed methane industry is still relatively young, and few studies exist of the development and evolution of an individual coal-bed methane play (a group of strata characterized by similar aspects of methane occurrence); thus, few models are available for planning the development of coal-bed methane resources on a broader scale. Studies now underway by the U.S. Geological Survey (USGS) are designed to develop such models and to further our ability to assess accurately the potential U.S. coal-bed methane resource.

\section{The Resource: Methane from Coal}

During coalification, large quantities of methane-rich gas are generated and stored within the coal on internal surfaces. Because coal has such a large internal surface area, it can store surprisingly large volumes of methane-rich gas; six or seven times as much gas as a conventional natural gas reservoir of equal rock volume

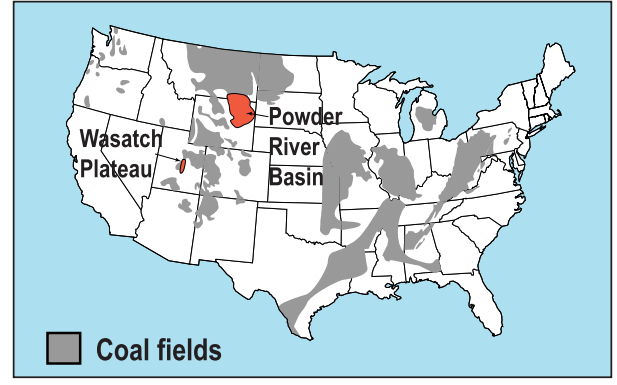

Figure 1. Major coal fields of the conterminous United States. The Wasatch Plateau and the Powder River Basin are producing coal-bed methane and are being studied by the USGS.

can hold. In addition, much of the coal, and thus much of the methane, lies at shallow depths, making wells easy to drill and inexpensive to complete. With greater depth, increased pressure closes fractures (cleats) in the coal, which reduces permeability and the ability of the gas to move through and out of the coal. Exploration costs for coal-bed methane are low, and the wells are cost effective to drill. Methane occurs in most coals, and the location of the Nation's coal resources is already well known (fig. 1). Methane from coal is thus an attractive resource.

Increased production of coal-bed methane, however, carries with it some technological and environmental difficulties and costs. In a conventional oil or gas reservoir, for example, gas lies on top of oil which, in turn, lies on top of water. An oil or gas well draws only from the petroleum that is extracted without producing a large volume of water. But water permeates coal beds, and its pressure traps methane within the coal. To produce methane from coal beds, water must be drawn off first, lowering the pressure so methane can flow out of the coal and to the well bore (fig. 2). This water, which is commonly saline but in some areas can be potable, must be disposed of in an environmentally acceptable manner. Surface disposal of large volumes of potable water can affect streams and other habitats, and subsurface reinjection makes production more costly. In addition, methane is a greenhouse gas; in the atmosphere it acts

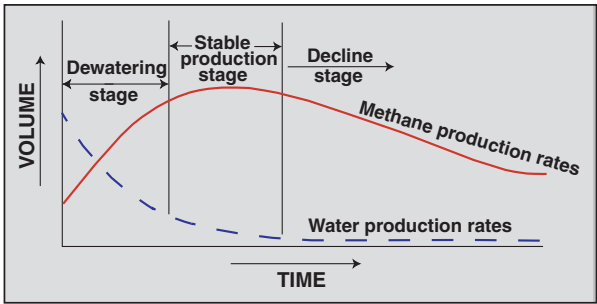

Figure 2. Typical production curves for a coal-bed methane well showing relative volumes of methane and water through time. Modified from Kuuskraa and Brandenberg (1989).

to trap heat and thus contributes to global warming.

\section{USGS Activity}

The USGS research will provide information that is vital to understanding the potential for, and the problems of, developing coal-bed methane as a part of the national energy mix. USGS studies will-

- Establish detailed models of the development and evolution of coal-bed methane plays in the Wasatch Plateau and Powder River Basin (fig. 1) and

- Improve assessment techniques for coal-bed methane resources.

\section{Wasatch Plateau and Powder River Basin}

The Wasatch Plateau, Utah, and the Powder River Basin, Wyoming and Montana, are two of the newest, most productive areas of coal-bed methane activity in the United States (fig. 1). The USGS is studying these regions to characterize the geologic and hydrologic controls on coalbed methane generation and production. This study will-

- Determine the distribution, thickness, rank, gas content, and burial history of coal beds.

- Characterize the cleats that allow methane to move through the bed. This work is instrumental to developing predictive models for recovery of coal-bed methane.

- Analyze the organic and geochemical composition of the coal and how these factors relate to gas content, composition, distribution, and recoverability. 
- Develop regional models of fluid flow to understand the variability of methane production and to help plan for the disposal of produced water.

- Analyze the composition of produced waters to construct models that predict water quality and assess the effects of injected waters on the strata into which they are placed.

\section{Coal-Bed Methane Assessment Methodology}

The 1995 National Assessment of United States Oil and Gas Resources (Gautier and others, 1996) provided assessments of only selected coal-bed methane plays. Now the USGS is developing new assessment tools and modifying established methods to provide a more comprehensive assessment of coal-bed methane resources in the United States. This study will_-

- Review coal-bed methane plays used in the 1995 assessment and reanalyze those plays as new data are incorporated,

- Define possible new coal-bed methane plays,

- Modify old and develop new assessment methodologies, and

- Assess coal-bed methane resources of the United States.

\section{The Concerns \\ Produced Water}

In a coal-bed methane well, water is produced in large volumes, especially in the early stages of production; as the amount of water in the coal decreases, gas production increases (figs. 2 and 3). The water must be disposed of safely. Most frequently, water is reinjected into subsurface rock formations. In some cases, the

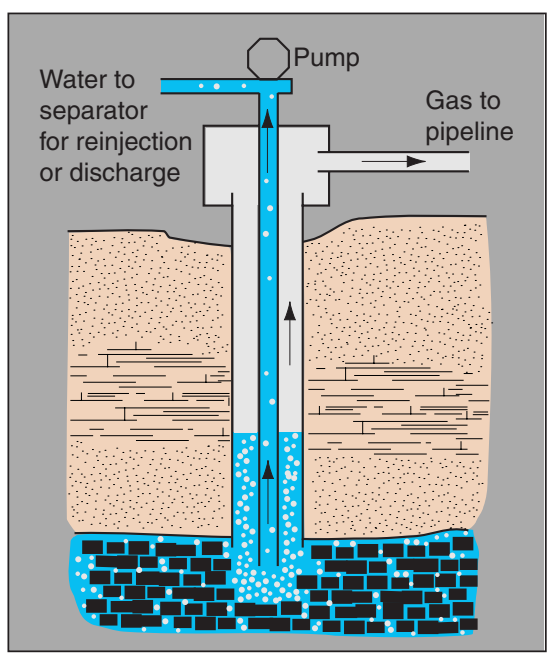

Figure 3. Diagram showing the production scheme of gas and water for a typical coal-bed methane well. water is allowed to flow into surficial drainages or is put into evaporation ponds (fig. 4). In cold regions, it is possible to freeze the water in the winter, collect the salts that separate out, and dispose of or utilize them independently of the water, which can be discharged.

\section{Methane in the Atmosphere}

Methane in the atmosphere has been increasing at a rate of 1 percent per year during the past 15 years (Rice, 1997).

Natural systems-wetlands and swamps, for example, and decomposing forest materials-account for about 40 percent of the methane released to the atmosphere. The balance is the result of human activity, though only about 10 percent of this is attributed to methane production; the remainder comes from such activities as rice cultivation, livestock, landfills, and biomass burning. Production of methane from coal beds may actually reduce methane emissions to the atmosphere by removing the gas that is otherwise released during coal mining. As part of the President's Climate Change Action Plan, established in 1993, coal-mine operators are being encouraged to recover and use coal-bed methane for energy.

\section{Methane Migration}

In some areas, methane migration may have contaminated ground-water sources, and methane may have migrated into residential neighborhoods. The controls on methane migration, however, are unclear. Some contamination may come from migration of methane along natural fractures; some may come from older gas wells that tapped reservoirs in sandstones associated with the coals. Some may come from new coal-bed methane wells. Reports from the 1800's document gas bubbles in water wells, in streams, and in fields after heavy rains; this evidence suggests that migration has always existed. It has now become a problem because of new residential development near the methane migration pathways. Studies by the USGS will help clarify the nature of methane migration.

\section{The Bottom Line}

The conterminous United States has estimated coal-bed methane resources of at least $700 \mathrm{TCF}$; about $100 \mathrm{TCF}$ appears to be economically recoverable with existing technology. Burning methane adds considerably less carbon dioxide to the atmosphere than does the burning of coal,

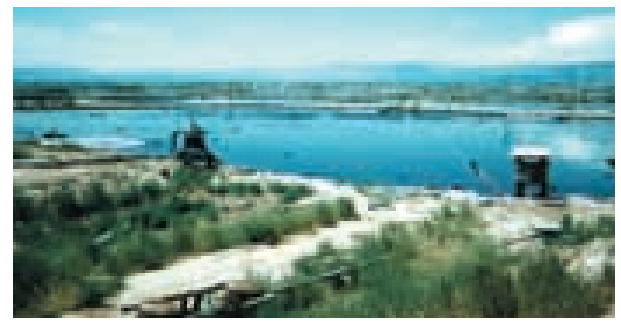

Figure 4. Production-water evaporation pond. Photograph provided by Cyndi Rice, USGS.

and production of methane from coals prior to mining reduces the amount of methane released to the atmosphere during the mining process. Producing methane then can serve a double purpose in the campaign to reduce the release of gases that contribute to global warming.

Increased production and use of coalbed methane, however, require a new understanding of its origin and distribution within coals, new approaches that will provide a variety of appropriate alternatives for the disposal of produced waters, and engineering studies that will augment the current understanding and recovery of this unique resource. Studies now underway as part of the USGS Energy Resources Program speak to all these issues.

\section{References Cited}

Gautier, D.L., Dolton, G.L., Takahashi, K.I., and Varnes, K.L., eds., 1996, 1995 National Assessment of United States Oil and Gas ResourcesResults, methodology, and supporting data: U.S. Geological Survey Digital Data Series DDS-30, release 2, one CD-ROM.

Kuuskraa, V.A., and Brandenberg, C.F., 1989, Coalbed methane sparks a new energy industry: Oil and Gas Journal, v. 87 , no. 41 , p. 49-56.

Rice, D.D., 1997, Coalbed methane-An untapped energy resource and an environmental concern: U.S. Geological Survey Fact Sheet FS-019-97. (Available only on the web at http://energy.usgs.gov/ factsheets/Coalbed/coalmeth.html)

For more information, please contact:

Vito Nuccio

U.S. Geological Survey, MS 939

Box 25046

Denver Federal Center

Denver, CO 80225-0046

Telephone: 303-236-1654

E-mail: vnuccio@usgs.gov 